\title{
Can The United Nations Security Council Be Democratized?
}

\author{
Aderemi Opeyemi Ade-Ibijola (Corresponding author) \\ Department of Politics, University of KwaZulu Natal \\ Pietermaritzburg, South Africa \\ E-mail: adeibjope@gmail.com
}

Received: August 8, 2015 Accepted: September 9, 2015 Published: October 24, 2015

doi:10.5296/ijch.v2i2.8477 URL: http://dx.doi.org/10.5296/ijch.v2i2.8477

\begin{abstract}
The quest for the democratization of the United Nations Security Council (UNSC) is one of the most critical issues that has confronted the United Nations (UN) system for the better part of the organization's existence. To this end, this paper examines the call for the democratization of the UNSC and the challenges thereof. It argues that the attempts to democratize the UNSC has been unsuccessful due to fact that the UNSC was not designed to be a democratic organ from its inception. The paper submits that a democratically constituted UNSC will lead to chaos and disorder in the international system.
\end{abstract}

Keywords: United Nations, United Nations Security Council, United Nations General Assembly, Permanent Five, Cold War, Second World War, Security Council, General Assembly, Non-Aligned Movement, African Union, High Power Panel

\section{Introduction}

The demand for the expansion of the United Nations Security Council (UNSC) Permanent membership is one of the most popular issues which have been a major challenge to the United Nations Organization since its establishment in 1945. The representatively disadvantaged member states on the United Nations Security Council UNSC had for decades articulated the need to have the United Nations (UN) founding charter amended in order to accommodate the changes which have taken place in the international system in the post-Second World and Cold War eras. The premium placed on the UNSC permanent membership club stems from its prestigious status and the supremacy of its decision making authority on issues that pertain to international peace and security. Consequently, the UNSC permanent membership club has become arguably one of the most attractive and sought after positions of power and influence in the history of global diplomacy. 
The increasing agitations by member states whose regions are under-represented in the permanent membership of the UNSC has fired the ambitions of the world's emerging economic and regional giants such as Japan, Germany, India, Brazil, Indonesia, Nigeria, South-Africa and Egypt to seek permanent seats on the UNSC in the past few decades (Guzzardi and Mullenbach, 2008). In light of the above synopsis, this paper is divided into three sections: first is the methodology that explains the approach used in writing this paper, the second focuses on the historical background to the UN Security Council reform, while the third part addresses the theme of this paper: 'Can the UN Security Council Be Democratized?' This is followed by the conclusion.

\section{Methodology}

The author used the qualitative approach in writing this paper. The study examined relevant literatures that included internet sources, and scholarly/academic journals. Thus the paper is contextually narrative and descriptive in nature.

\subsection{Historical Background to UN Security Council Reform}

The UN represents the most sophisticated and arguably the best machinery so far established for the promotion of international peace and security because it is vested with powers to make far-reaching decisions on global affairs, especially those that bothers on international peace and security. ${ }^{1}$ The UN commenced its multilateral diplomatic activities in 1945 with 51 independent member states. Since then, the organization's membership has grown significantly to 193 as at the time of writing this paper. ${ }^{2}$ The enormous powers wielded by the UN is drawn from its founding charter.

At the termination of hostilities between the East and West following the end of arguably the most protracted ideological warfare ever known in human history - the Cold War, a new World order emerged following the collapse of the old bipolar world. One of the immediate consequences of this development was the desire for the reconfiguration of the UNSC which had been expressed strongly by some member states within the UN who felt that their countries deserves permanent membership seats on the basis of their regional standing, economic credentials/potentials, huge financial, diplomatic and military contribution to UN activities and undertakings; as well as their historical contributions to the maintenance of peace and regional stability in their spheres of influence.

Since it came into existence in 1945, the bulk of the UN activities have been conducted in the United Nations Security Council UNSC. The hegemonic control of the UN machinery by it Security Council (SC) component is considered by many observers to be at par with that of an upper house of a legislature in national politics. ${ }^{3}$ While the General Assembly (GA) is recognized in the UN charter as the main deliberative organ of the UN that provides a unique forum for multilateral discussion of issues of global importance among its 193 member states, the unsatisfactory reality which had prompted member states over the years to demand for

\footnotetext{
1 See Akindele R.A. (2005). "Nigeria at the United Nations: An Overview", in Nigeria and the United Nations Security Council, Bola. A. Akinterinwaed, (Vantage Publishers Ibadan, Nigeria).

2 See "Growth in United Nations membership, 1945 - present", available at www.un.org/en/members/growth.Shtml.

${ }^{3}$ H. A. Saliu and J. S. Omotola (2008) “Can Nigeria Get a UN Security Council Seat?" South African Journal of International Affairs, Vol. 15, No. 1, June.
} 
reform is that the GA has had to play a second fiddle to the SC in authoritative and power sense despite being the most representative organ of the world body. For instance, the GA decisions are considered to be advisory and unbinding on member states unless such decisions receive the ratification of the permanent five members who may decide to ratify such decisions provided they do not infringe on their national interests. If they do, then they are empowered by the UN charter to veto them thus placing the permanent five members in the driving seat and also in a position of unchallengeable supremacy as far as the UN architecture is concerned. This has made it possible for the veto holding permanent members of the SC to control the destiny of the UN since its inception. What this implies therefore is that the SC is the soul of the UN system while other organs and agencies represents the component parts of it body.

The exclusive veto powers enjoyed by the permanent five had on several occasions been recklessly used more as a vindictive instrument and for the preservation, and the perpetuation of great powers' interests. As Akindele and Akinterinwa noted in 2011: “. . . the manifestation of the strength and prestige of the Security Council, which is the veto power of its permanent members, has paradoxically also been the source of the Council's political paralysis." The authors advanced their argument thus: "The veto power had often been recklessly used and was usually put in the service of parochial national interests. It had, to that extent, often been exercised detrimentally to the collective interests of the United Nations."4 This submission can safely be justified on the basis of what transpired during the protracted struggle against apartheid in South Africa when the United States and other key western countries such as Britain and France vetoed several resolutions which sought to impose stiffer sanctions on the defunct apartheid regime of South Africa. As a matter of fact, the main reason why it took such a long time to bring down the apartheid edifice in South Africa was largerly due to the reckless use of the veto power particularly by the Western trio of United States, France and Britain which considered their national interests supreme to issues of global concern however grave they might be. The SC thus serves to "keep the big players in the game, and there is no game without them."

Moreover, the call for the SC reform is further reinforced by the fact that it is the only organ of the UN system whose decisions are binding on all members regardless of whether the decisions are favorable to them or not - members are obliged to observe compliance. The popular saying in representative democratic parlance that the minority will have their say while the majority will have their way does not apply as far as the configuration and the operations of the UNSC is concern because the majority, in this case the GA always have their say while the power laden minority - the SC Permanent five always have their way. This enviable towering status, coupled with the changing terrain of the $\mathrm{UN}$ and international

\footnotetext{
${ }^{4}$ Akindele R.A. and B. A. Akinterinwa (2011) "Reform of the United Nations: Towards Greater Effectiveness, Enhanced Legitimacy Profile and Equitable Regionally - Balanced Membership in An Enlarged UN Security Council” in Africa and the UN System: The First Fifty Years, G. A. Obiozor and AdekunleAjaja (eds.), Nigerian Institute of International Affairs (NIIA), Publishers, Lagos, Nigeria, p. 204.

${ }^{5}$ Cited by H. A. Saliu and J. S. Omotola (2008) “Can Nigeria Get a UN Security Council Seat?" South African Journal of International Affairs, Vol. 15, No. 1, June 2008, p. 72.
} 
politics in general, has intensified calls for its reform ${ }^{6}$. The call for the reform of the UN especially the SC permanent membership veto club has lingered for decades without success perhaps due to the perception that "the UN has never taken happily to internal reform, that it is an inflexible institution set in its ways and unwilling to change." Implicitly, the slow attempt to reform the UN system particularly the $\mathrm{SC}$ has been tortuous because of its configuration from the very beginning which makes it "inflexible" to structural alteration.

The attempt to reform the UN has hitherto exhibited symptoms that suggest the possibility of preserving the power status quo, as Saliu and Omotola suggest, "the superficiality of the attempt to reform the UN so far may be connected to the elevation of power over justice in the internal workings of the organization, especially in the Security Council where the power of the veto takes precedence. ${ }^{8}$ Despite this dilemma, the call for a fundamental reform of the SC still persists. Nigeria, one of the aspiring African countries for the SC permanent seat has been supportive of the reform because of the potential advantage it will offer the country to represent Africa at the highest level in World politics. Historically, the UNSC had undergone restructuring once although several attempts have been made to attain this much desired goal over the years beginning from the late 1940s to the early 1950s.

The emergence of several countries from colonial subjection and subsequent admission into the UN necessitated the call for an expansion of the non-permanent seats on the UNSC from six to eight. The campaign to bring this about was spearheaded by Spain and a nucleus of Latin American countries which proposed an amendment to the UN charter in 1956 seeking to expand the number of non-permanent seats on the UNSC from 6 to 8. It however took years to achieve this objective due mainly to the intense debates and inter- great powers disagreement, which included the Soviet Union's insistence that the issue of UNSC restructuring should be tied to the issue of mainland China's membership in the UN, a stalemate later ensued on this issue until an agreement was reached in 1963 when the GA approved the amendments that increased the non-permanent seats membership from six to ten -the amendments was later ratified by the SC (Bourantonis, 2005). This was two seats more than the originally anticipated number Eight.

The wave of decolonization which blew away the colonial structures and their controllers in its wake also had a corresponding significant effect on the UN system as its membership rank swelled from the mid-1960s to the late 1970s. During this period, developing countries were increasingly discontented with the reckless abuse of the veto power by the so - called permanent five members; they were also seriously concerned about the lack of "equitable representation" for the continents of Asia and Africa on the UN councils. To address the seeming imbalance, in 1979 and 1980 respectively India and a host of other countries from Africa, Asia, and Latin America proposed an increase of the non-permanent membership

\footnotetext{
${ }^{6}$ See H. A. Saliu and J. S. Omotola (2008) “Can Nigeria get a UN Security Council Seat?” South African Journal of International Affairs, Vol. 15, No. 1, June.

7 S. Schlesinger “Can the United Nations Reform?”, World Policy Journal, 14.3, Fall 1997, p. 3.

${ }^{8}$ See H. A. Saliu and J. S. Omotola (2008) "Can Nigeria get a UN Security Council Seat?" South African Journal of International Affairs, Vol. 15, No. 1, June, p. 73.
} 
seats of the SC from 10 to $16{ }^{9}$ Suffice to say that unlike the successful attempt to restructure the SC in the early 1960s the latter efforts to achieve the earlier success failed to produce the desired results because of the Cold War battles between the U.S, the Soviet Union and their respective allies. ${ }^{10}$

The impact of the Cold War on global affairs foreclosed the possibility of having the UN consider any request for the expansion of the SC in the 1980s but with the end of the Cold War in the early 1990s, there was a rekindled interest in restructuring the SC to reflect the changes which had occurred in the international political space. Thus in December 1992, the GA approved an Indian sponsored resolution which called upon the UN Secretary General to invite member - states to submit proposals for SC reforms, this later culminated into the harvest of proposals from 80 countries. In 1993, the GA established an "Open-Ended Working Group" to consider the various proposals for reforms; several options were subsequently canvassed in the various proposals submitted to the working group for the restructuring of the SC. This included a proposal by the Non-Aligned Movement (NAM) - a group of countries which stood aloof of the Cold War ideological crisis called for an increase in permanent membership seats from 5 to 9 . As for the non-permanent seats, the group proposed an increase in representation from 10 to 17 because the UN had not as at the time responded accordingly with regard to the proposals submitted by India and other member states in 1979 and 1980 which suggested the expansion of the non-permanent seats. ${ }^{11}$

At the commemoration of its $50^{\text {th }}$ anniversary in 1995, the UNGA approved the Declaration of the United Nations, stating expressly that the SC should be "expanded and its working methods continue to be reviewed in a way that will further strengthen its capacity and effectiveness, enhance its representative character, and approve its working efficacy and transparency." 12 Two years after, the Malaysian UN Ambassador Ismael Razali, who also was the President of the GA 1996-1997; and the then Chair of the Open-Ended Working Group presented a proposal suggesting the addition of a non - veto holding five permanent seats and four non-permanent seats to the SC. The Malaysian envoy's proposal which allowed the UNGA to pick the countries it deemed eligible to take up the proposed seats was later blocked by members of the NAM and a host of other member states of the UN such as Egypt, Italy, Mexico, and Pakistan (Bourantonis, 2005). Razali's proposal was blocked by the NAM group which saw the plan as a threat to their internal cohesion, along with Italy, who sought to block the permanent membership bid of Germany and Japan. ${ }^{13}$ The Italian opposition to Germany and Japan's SC permanent membership bids is historically ironic

\footnotetext{
9 See J. E. Guzzardi and M. J. Mullenbach (2007-2008) “The Politics of Seeking a Permanent Seat on the United Nations Security Council: An Analysis of the Case of Japan,” Midsouth Political Science Review, Vol. 9.

${ }^{10}$ See D. Archibugi (1993) “The Reform of the UN and Cosmopolitan Democracy: A Critical Review," Journal of Peace Research, 30 (3).

${ }^{11}$ See J. E. Guzzardi and M. J. Mullenbach (2007-2008) "The Politics of Seeking a Permanent Seat on the United Nations Security Council: An Analysis of the Case of Japan” Midsouth Political Science Review, Vol. 9.

${ }^{12}$ Ibid., p. 38.

13 See Gordon N. "Pathways To Security Council Reform", Center On International Cooperation, New York University, United States, May 2014, available online at: www.cic.nyu.edu.
} 
given the fact that the trio of Italy, Japan, and Germany were allies during the Second World War. The enviable economic and technological successes which have been recorded by Germany and Japan might have played a major role in Italy's continued opposition to its ex-allies bids for SC permanency. Tokyo and Berlin occupy the third and fourth positions respectively in the global ranking of the World's most powerful economies ${ }^{14}$

Following a decade of intensive agitations and debates for the SC reform, the UN Secretary-General Kofi Annan in 2003 set up a 16 - member high level panel to consider and recommend the appropriate options for the restructuring of the SC. In 2004, the panel came up with recommendations which proposed two different options for the SC restructuring which are as follows: Option (A) six new permanent seats without veto power and three additional non-permanent seats; Option (B) eight four year renewable seats and one additional non - permanent seat (Blum, 2005, Price, 2005). The UNGA debated these options and others passionately for the better part of year 2005; they were, however, unable to reach a consensus on how to restructure the SC. The African Union (AU) on its part responded to these proposed options by choosing the first option following the decision of the Heads of States and Governments of Africa in their mid-term submit held in Abuja, Nigeria in January 2005. ${ }^{15}$ This position was subsequently ratified and adopted by the African Union on 8 March 2005, in Addis Ababa, and became the continent's official position with regard to the reform of the SC. ${ }^{16}$

The failed attempt to restructure the SC in 2005 was deeply frustrating. In the words of Brazilian Ambassador Ronaldo Mota Sardenberg whose country nurses a permanent seat ambition for the SC, the debates on the reform of the SC was unsuccessful because a "few countries, seeking to avoid any decision on this matter, take refuge on claims for consensus and on allegations on the disruptive nature of the issue." ${ }^{17}$ Implicitly, some states were non-assertive on the issue perhaps due to their naivety or acting under the influence of some powerful states that might have dissuaded them from taking part actively in the process of the SC reform debates. According to Ambassador Sardenberg, the actions and disposition of those countries with regard to the issue of the SC reform "only contribute to the perpetuation of current inequalities in the structure of the organization, and to the frustrations of the aspirations of all members, for a more balanced distribution of power in the work of the Security Council." 18

The proposed UN reform had since 2005 when the High Power Panel (HPP) submitted its report mellowed. The implication of this is that the UN itself seems not to be favourably disposed to carrying out the much needed SC reforms. As enshrined in its Charter, the requirements for the expansion of the SC permanent seats entails aspiring permanent

\footnotetext{
14 “GDP Current US\$” World Development Indicators World Bank, 2013.

${ }^{15}$ See H. A. Saliu and J. S. Omotola (2008) “Can Nigeria get a UN Security Council Seat?" South African Journal of International Affairs, Vol. 15, No. 1, June.

${ }^{16}$ Ibid.

${ }^{17}$ Cited by J. E. Guzzardi and M. J. Mullenbach (2007-2008) "The Politics of Seeking a Permanent Seat on the United Nations Security Council: An Analysis of the Case of Japan,” Midsouth Political Science Review, Vol. 9, p. 38.

${ }^{18}$ Ibid., p. 38.
} 
membership seeking countries to first secure the nod of not less than two-third of the entire membership of the UN, which includes the Permanent five members, to ratify an amendment to the UN Charter. In addition, aspiring countries must also do a thorough diplomatic homework at regional and continental levels in order to win the much needed support required to strengthen their case for the SC seat.

\subsection{Can the United Nations Security Council Be Democratized?}

The above heading represents one of the most frequently asked questions across academic and diplomatic circles with regard to the proposed reform of the UN system. A world that is plagued by armed conflicts and other destabilising forces will undoubtedly need a truly representative Security Council SC that will maintain, and advance international peace and security without nationalistic sentiment and bias. Since the SC plays a decisive and active role in the maintenance of international peace and security, its past failures are glaring. Thus, the clamour for its reform is more urgently sought than ever. Nonetheless, the path to reform has been full of difficulties down the years. While countries have agreed on the Council's representative deficiencies, they have differed on what should be the solution to the problem identified. $^{19}$

As earlier mentioned, the popular sentiment among the UN member states is that the SC membership composition and its institutional apparatus is reflective of the old geopolitical realities and political thoughts of which the 1945 world played a defining role. The five permanent veto power holders of the SC which enjoy many exclusive privileges have come under a barrage of criticism - which earned them the titles of a "self-appointed" and 'self-enthroned oligarchy' in the process. ${ }^{20}$

Despite decades of debates on the SC reform in the United Nations General Assembly UNGA, the anticipated change in the Council's configuration still remains elusive. ${ }^{21}$ Proposals have been presented on many occasions by member states of the UN who are desirous of reform but no membership plan has yet secured the support required to actualize a major institutional structural change in the UN system. Although the calls for SC reform had, as mentioned earlier, been in existence since the late 1940s, these calls intensified in the early 1990s, following the SC's controversial action and inaction in (Iraq and Rwanda). ${ }^{22}$ While the SC's 1990 decision on Iraq was widely believed to be appropriate and in accordance with its Charter role, its failure to act rapidly to save the Rwandan humanity from extinction was colossal. It was described as "the failure of the UNSC to organize effective action to prevent the Rwandan genocide..."23

As a consequence of the above scenarios, the SC's increasing activities, especially after the Cold War, have forced critics to be more vociferous in their demand for reform. According to

\footnotetext{
19 See J. Paul and C. Nahory (2005) “Towards a Democratic Reform of the UNSC.” Global Policy Forum, July 13, available online at: https://www.globalpolicy.org/security/41131.html.

20 Ibid.

${ }^{21}$ Ibid.

${ }^{22}$ Ibid.

${ }^{23}$ See Martin E. Ridley (2009) "Have the Problems Leading to the Failure of the UN Security Council to organize Effective Action to Prevent the Rwandan Genocide Now Been Rectified?" available online at: www.academia.edu.
} 
Nahory (2005), the apostles of reform have demanded that the SC be: (a) more representative, (b) more accountable, (c) more legitimate, (d) more democratic (e) more transparent, (f) more effective and, (g) more fair and even-handed (that is, no double standards in the discharge of responsibility). ${ }^{24}$ These demands are no doubt reasonable and well - articulated. However, the structural make - up of the UN system seems not to have been factored before coming up with these demands. It will take a radical amendment of the UN Charter for these demands to be met - a possibility that exists only perhaps in the minds of those advocating for reform. A SC membership of 30,40 , or even 50 undoubtedly harbours the possibility of being more representative across the regional and continental spectrums.

The main desire of the proponents of UN reform is to weaken the enormous powers of the permanent five members - the "oligarchs" and create a more diverse and representative system. But, to start with, the reform advocates have got to first and foremost contend with this question: How does a system that was not founded on democratic principles be democratized? The question posed indicate that the quest for reform of the SC and the founding Charter of the UN is replete with problems. Proffering answer to the above question will begin with a brief historical reflection so as to ascertain whether the UN was from its inception designed to be a democratic organ.

Prior to the emergence of the UN in 1945, the drafters and signatories to its Charter were not oblivious of the factors that contributed to the collapse of the League of Nations, the precursor to the UN. According to Fred Aja Agwu, the UN system was not designed from the outset to be democratic (especially its SC organ). In his words: "You cannot have democracy in the international system because that system as we have it today was birthed on the axis of war. It was the booty of the victorious powers." $25 \mathrm{He}$ stated further that one of the contributory factors to the failure of the League of Nations that preceded the UN was the attempt to democratize it.

Although it was a passive democratization in the sense that the decision to respond to any breach of peace or act of aggression at that time was reserved to individual nations to decide not for a collective body such as the UNSC - that was why Italy invaded Ethiopia and Japan invaded China's north - eastern region of Manchuria and the league of Nations did not do anything. The formation of the UN was influenced by those unfortunate experiences that was why there is a central organ in which the SC under article 39 of the Charter is bestowed with the responsibility to determine the breach of peace, threat to peace and act of aggression and decide on what decision to take should any of these situations occur. Article 25 obligates member states to support the SC in this regard. ${ }^{26}$

So, democratizing the SC will be anarchical in the sense that the veto powers hitherto enjoyed by the Permanent five in order to enable them forestall any possibility of confrontation with one another will be expanded. Such scenario will definately lead to systemic confusion. That

\footnotetext{
${ }^{24}$ J. Paul and C. Nahory (2005) "Towards a Democratic Reform of the UNSC." Global Policy Forum, July 13, available online at: https://www.globalpolicy.org/security/41131.html, p. 1.

${ }^{25}$ Personal Interview with Associate Professor Fred Aja Agwu, Senior Research Fellow at the Nigerian Institute of International Affairs, NIIA, Lagos, Nigeria, 16-01-2014

${ }^{26}$ Ibid.
} 
explains why the High Level Panel (HLP) did not recommend that additional seats should carry veto power - the veto issue was totally not within the picture. The configuration of the international system is averse to democratization because it is "built on power politics and not on democratic principles." 27 If it is democratized, it will not work. The democratic principle is working in the GA where member states are allowed to articulate their views but the $\mathrm{SC}$ is where the action lies. So the SC is not an organ created on democratic principles hence the recommendation of the HLP.

In light of the foregoing, the advocates of SC reform faces a stern test in their quest for democratization of this UN organ which, as mentioned above, will take an unprecedented amendment of the UN Charter to attain. That is why the UNSC reform seekers often ask: how can even the best - organized Council perform effectively and fairly bearing in mind that we live in a world where great powers use the instrumentality of their power status to the disadvantage of the less powerful ${ }^{28}$ Over the years, powerful governments that pride themselves as champions and apostles of "freedom", "democracy," and "good governance", have acted at variance with what they preach. These countries behave despotically in the international realm, bending states to their will and caprice; and acting in clear violation of international law which they are obligated to uphold and protect. Ironically such powers sit in the UNSC and cannot expect to solve problems that they themselves birthed. This has been described as the "foxes guarding the chicken coop" problem. ${ }^{29}$ Consequently, the call for democratic reform of the UNSC has the potential to multiply this problem; and if this is allowed to happen, the resultant effect might be unpalatable.

An enlarged UNSC permanent membership with veto power will undoubtedly culminate into a conglomeration of powerful countries that will be there to pursue their national interests at each other's expense. For instance, should Japan emerge as a veto holding permanent member, it will definitely usher in a period of intense rivalry between the country and its Asian neighbor - China. This perhaps informed China's decision to announce to the world that it will block permanent membership seat for Japan through the instrumentality of its UNSC veto power status. The decision to expand or maintain the current configuration of the SC will ultimately be decided by the UNSC permanent five. Hence, aspiring countries (Japan included) have a tough task ahead of them.

As earlier said, enlarging the UNSC to allow for democratization may be counterproductive. As Paul and Nahory noted in 2005: "enlarging the oligarchy by adding five or six other powerful governments, more permanent members would scarcely make the Council more representative, accountable, transparent, legitimate or even-handed." 30 The authors argued further that the real force pushing the aspirant countries is self-interest and not the quest for democratization as they would want the international community to believe. They said, "Self-interest, not democracy, motivates these membership claims and a Council loaded with

\footnotetext{
27 Ibid.

${ }^{28}$ See J. Paul and C. Nahory (2005) “Towards a Democratic Reform of the UNSC.” Global Policy Forum, July 13, available online at: https://www.globalpolicy.org/security/41131.html

${ }^{29}$ Ibid.

${ }^{30}$ Ibid.
} 
more permanent members would suffer from gridlock and political sclerosis. $" 31$

Sean Murphy corroborated this view by pointing out the potential problems that will befall the SC if it is enlarged. He said: “. . . widespread participation . . . makes political consensus more difficult to achieve and political cohesion more difficult to maintain; faced with the complex problems regarding whether aggression has occurred, and whether and how to respond, widespread participation jeopardizes the ability of the system to work at all." ${ }^{, 32}$ One fact that does not support the democratization of the SC is that even with the present composition of the Permanent five "oligarchy" club, decisions are sometimes very difficult to reach due largely to conflicting great power interests; thus it will be potentially dangerous if the UNSC is democratized.

\section{Conclusion}

While the reform of the UN system is necessary, the call for its democratization is out of place and at variance with the realities of the international system. Consequently, the advocates of a representatively balanced UNSC should take cognisance of the fact that the UNSC permanent membership club was design principally as a check and balance mechanism by the Permanent five members to checkmate their own excesses. Democratizing the UNSC therefore will put global peace and security in jeopardy as decisions will become more difficult to reach. As an organ whose decisions particularly those that bothers on international peace and security are sacrosanct and impactful on the humanity concern, entrenching democratic principles into the UNSC will instill confusion and systemic disorder into the organization because the UN system itself was not erected on democratic pillars. As indicated above, the only thing that can be done to bring about the much desired democratization will be a complete review of the UN Charter which seems very unlikely given that the Permanent five members themselves must give their consent for such plans to materialize. This places the ambitions of the UNSC permanent membership seeking countries in a dicey situation.

\section{References}

Akindele, R. A. (2005). Nigeria at the United Nations: An Overview, in Nigeria and the United Nations Security Council, Bola. A. Akinterinwa (Ed.), Vantage Publishers Ibadan, Nigeria.

Akindele, R. A., \& Akinterinwa, B. A. (2011). Reform of the United Nations: Towards Greater Effectiveness, Enhanced Legitimacy Profile and Equitable Regionally - Balanced Membership in An Enlarged UN Security Council, in Africa and the UN System: The First Fifty Years, G. A. Obiozor and Adekunle Ajaja (Eds.), Nigerian Institute of International Affairs (NIIA), Publishers, Lagos, Nigeria, p. 204.

\footnotetext{
31 Ibid.

32 Cited by Akindele R.A. and B. A. Akinterinwa (2011) "Reform of the United Nations: Towards Greater Effectiveness, Enhanced Legitimacy Profile and Equitable Regionally - Balanced Membership in An Enlarged UN Security Council, in Africa and the UN System: The First Fifty Years, G. A. Obiozor and AdekunleAjaja (eds), Nigerian Institute of International Affairs (NIIA), Publishers, Lagos, Nigeria, p. 209.
} 


\section{Macrothink}

Archibugi, D. (1993). The Reform of the UN and Cosmopolitan Democracy: A Critical Review. Journal of Peace Research, 30(3). http://dx.doi.org/10.1177/0022343393030003005

GDP Current US\$ World Development Indicators World Bank, 2013.

Gordon, N. (2014). Pathways to Security Council Reform, Center on International Cooperation, New York University, United States. Retrieved from http://www.cic.nyu.edu

Growth in United Nations membership, 1945 - present. Retrieved from http://www.un.org/en/members/growth.Shtml

Guzzardi, J. E., \& Mullenbach, M. J. (2008). The Politics of Seeking a Permanent Seat on the United Nations Security Council: An Analysis of the Case of Japan. Midsouth Political Science Review, 9.

Paul, J., \& Nahory, C. (2005). Towards a Democratic Reform of the UNSC. Global Policy Forum, July 13. Retrieved from https://www.globalpolicy.org/security/41131.html

Personal Interview with Associate Professor Fred Aja Agwu, Senior Research Fellow at the Nigerian Institute of International Affairs, NIIA, Lagos, Nigeria, 14-01-16.

Ridley, M. E. (2009). Have the Problems Leading to the Failure of the UN Security Council to organize Effective Action to Prevent the Rwandan Genocide Now Been Rectified? Retrieved from http://www.academia.edu

Saliu, H. A., \& Omotola, J. S. (2008, June). Can Nigeria Get a UN Security Council Seat? South African Journal of International Affairs, 15(1). http://dx.doi.org/10.1080/10220460802217975

Schlesinger, S. (1997, Fall). Can the United Nations Reform? World Policy Journal, 14(3).

\section{Copyright Disclaimer}

Copyright for this article is retained by the author(s), with first publication rights granted to the journal.

This is an open-access article distributed under the terms and conditions of the Creative Commons Attribution license (http://creativecommons.org/licenses/by/3.0/). 